\title{
Interpreting Dancing as Symbols of Freedom in Remy Sylado's Namaku Mata Hari from Its Protagonist Personality
}

\author{
Noer Azisi ${ }^{1}$ ) \\ SMA Negeri Pintar Provinsi Riau Boarding School, Jln. Proklamasi Sei. Jering Kecamatan Kuantan Tengah
}

Kab. Kuantan Singingi, nurazisi1@gmail.com

\begin{abstract}
Andang Saehu' ${ }^{2}$ )
English Studies Department, Faculty of Humanities, UIN Sunan Gunung Djati Bandung, Jl. A.H. Nasution no 105 Cibiru Bandung 40614, andangsaehu@ uinsgd.ac.id
\end{abstract}

\begin{abstract}
This study interprets the 'dancing' as symbols of freedom expressed by a Dutch dancer, Mata Hari (alias Margaretha Geertruida Zelle) in Remy Sylado's Namaku Mata Hari, a protagonist novel. The data in this study are sentences or paragraphs containing dancing as symbols of freedom. Those sentences or paragraphs were collected by conducting library research through reading carefully the novel Namaku Mata Hari, coding each part of the novel showing the dancing as a symbols of freedom and the role of her id, ego and super ego, classifying data into symbols proposed by Hayek's (1960) and Hospers' (1984) theories, and analysing the data simultaneously. The result shows that the dancing as freedom symbols is interpreted in a lot of expressions: dancing expressing her freedom of being life, of taking back her rights, of avoiding Western aesthetic principles, of being peaceful state of mind, of finding her desire, of gaining a deep hypnotic trance, of gaining humanity instead of being prejudice of her nationality, and of avoiding Western civilization..
\end{abstract}

Keywords: Interpreting;Dancing; Freedom; Symbol; Namaku Mata Hari.

Abstrak

Penelitian ini berupaya menginterpretasikan tarian sebagai simbol kebebasan yang diungkapkan melalui kalimat-kalimat yang terdapat dalam Novel Remy Silado dengan judul Namaku Mata Hari. Kalimat-kalimat tersebut dikumpulkan dengan cara kajian pustaka melalui beberapa tahap: membaca Novel Namaku Mata Hari dengan seksama, memberi kode atau highlight terhadap beberapa bagian yang berkaitan dengan tarian sebagai simbol kebebasan dan peran id, ego, dan super ego sang protagonis, mengklasifikasi data berdasarkan teori tentang kebebasan dari Hayek (1960) dan Hospers (1984), dan menganalisis data secara simultan. Hasil penelitian ini menunjukkan bahwa tarian sebagai simbol kebebasan dapat diinterpretasikan dalam berbagai ungkapan: Tarian sebagai simbol kebebasan kehidupan (untuk hidup), simbol hak asasi manusia, simbol perlawanan terhadap estetika Barat, simbol perdamaian,, simbol hasrat, simbol kesadaran diri, simbol perikemanusiaan, dan simbol perlawanan terhadap peradaban Barat.

Kata Kunci: Interpretasi; tarian; kebebasan; simbol; Namaku Mata Hari. 


\section{Jurnal al-Tsaqafa Volume 15, No. 01, Juli 2018}

\section{Introduction}

Figurative language used in literature is one of the components that distinguishes a literary fiction with other forms of writings. While the other genres used direct and scientific languages, a literary fiction usually uses many figurative languages in it. This term covers a wide range of literary devices and techniques which include: simile, metaphor, personification, hyperbole, allusion, idiom, imagery, alliteration, assonance, consonance, metonymy, synecdoche, irony, pun, symbolism and many others. They make a literary work more beautiful, effective, persuasive, impactful, and meaningful.

One of the most important aspects in the language of a literary work is the sign, symbolism of the sounds from the words ${ }^{1}$. Symbolism as one of the examples of figurative language is often used by the author in order to bring out their implicit ideas, ideologies or messages to the readers. Therefore, symbolism plays an important role in literature because it stimulates the reader to think beyond the literal meaning of the literary fiction itself in the process of interpretation.

Every published literary work belongs to the readers. For this reason, the reader can express their opinions towards the literary work because literature is the final object

1 Rene Wellek \& Austin Warren, Teori Kesusastraan (Jakarta: Gramedia, 1990), 15. and what then become interpretation ${ }^{2}$. Interpretation is the attempt to know a meaning that exists in the literary work which is being analyzed. In this process, the readers will try to point out the author's intention in a particular symbol. Interpretation in the form of comments, analysis, review or critique can be different for every reader because this process can be done in various ways and approaches.

A symbol is usually interpreted by readers with many meanings. These difference interpretations of a symbol will eventually lead to ambiguity because every interpretation seems to have its own reason in choosing a certain meaning. This notion coincides with the definition given by Zhang (1998) that ambiguity is expression which have more than one semantically unrelated meaning ${ }^{3}$. In other words, an expression is ambiguous if it has several paraphrases which are not paraphrases of each other. Ambiguity that comes from the symbolism is an important thing in literature.

Remy Sylado's Namaku Mata Hari tells a story of the life of a real person, Mata Hari, who takes an important role in World War I. Mata Hari works as a double-agent for France and Germany at that time. She is chosen for this important task mostly

\footnotetext{
2 Tzvetan Todorov, Tata Sastra (Jakarta: Djambatan, 1985)

3 Qiao Zhang, "Fuzziness, Vagueness, Generality, Ambiguity," in Journal of Pragmatics 29(1), 13-31.
} 


\section{Interpreting Dancing as Symbols of Freedom in Remy Sylado's Namaku Mata Hari from Its Protagonist Personality}

because she shows a great knowledge of many things including her language ability and her understanding of political affairs. Despite of being a naked dancer and a prostitute, it is proven that she has a great deal of intelligence. For this reason, the researcher is interested to know the three personality structures of the protagonist.

Many questions across the researcher's mind when reading this novel, such as, why does not she choose a better job based on her intelligence and what makes her doing what she did. Furthermore, Remy Sylado's Namaku Mata Hari is full of symbolism. The word Mata Hari itself, for example, can be a symbol of a number of different things, thus, it can have numerous meanings according to its reader's interpretation. However, this research focuses only on interpreting "dancing" that symbolizes freedom to the novel's protagonist, Mata Hari, while also considers her personality structures - the id, the ego, and the super ego - that makes her the way she is.

Some previous studies on this novel show that Namaku Mata Hari's novel is, in different research topics, interesting to study. The first study was conducted by Sabariah (2011). She focused on gender perspective in examining the main character's intelligence ${ }^{4}$ of which it is different from this current study focus. Other study was conducted by Puspitaningrum (2013) focusing on examining the main character's motivation to be proud as a prostitute ${ }^{5}$ of which this is also different from the present study.

Another study was conducted by Kolb (2009) analysing Mata Hari's dance in the context of femininity and exoticism ${ }^{6}$. His study specifically explores the ideological and aesthetic framework within which she was embedded as a female artist in the context of related concurrent dance trends. One thing in common is although the novel Namaku Mata Hari has been studied previously by the previous researchers, this present study covers a new thing that has not been covered yet by them. This currect study is aimed at interpreting the 'dancing' as symbols of freedom expressed by a Dutch dancer, Mata Hari in Remy Sylado’s Namaku Mata Hari novel.

As the theoretical bases of the study, the researchers adopted several theoretical foundations to support the research findings and discussion, they are Freud (1940)

\footnotetext{
4 Dita Sabariah, Mata Hari Sebagai Perempuan Intelijen Dalam Novel Namaku Mata Hari Karya Remy Sylado: Sebuah Analisis Berprespektif Gender, Unpublished Paper.

5 Yohana Dwi Puspitaningrum, A Protagonist Self Predicament in Remy Sylado's Namaku Mata Hari: A Psychoanalysis Perspective, Unpublished Paper. ${ }^{6}$ Alexandra Kolb, Mata Hari's Dance in the Context of Femininity and Exoticism (Mandragora), 2009
} 


\section{Jurnal al-Tsaqafa Volume 15, No. 01, Juli 2018}

discussing id, ego, and super ego; Abrams (1999) and Augustine (in Nurrachman, 2017) talking about symbols; and Hayek (1960) and Hospers (1984) telling about freedoms. Each of whom is discussed in this section. Talking about Id, Ego, and Super Ego, the protagonist of this novel, Mata Hari, is very honest to show her primitive impulse regarding erotic wishes. She is not afraid of what people would think of her as long as she got what she wanted in order to have a peaceful state of mind. Many times she stated that she became the way she is because of her husband.

As the collected data were in the form of sentences or paragraphs, this study was designed in descriptive qualitative. Sudaryanto (1993:62) pointed out that descriptive method is used to describe the collected data, in this case the description or interpretation of dancing as symbols of freedom and the role of her id, ego and super ego, systematically. This notion coincides with the statement by Djajasudarma (2010:8) that the use of descriptive method in this study is to describe systematically and accurately the characteristics of data. The data were collected by doing library study consisting of reading carefully the novel Namaku Mata Hari, coding each part of the novel showing the dancing as a symbol of freedom and her personality development, classifying data into symbols, and analysing the data simultaneously (Seidman, 2006) and Cresswell (2012).

\section{A. FINDING AND DISCUSSION}

The data are not presented thematically but presented simultaneously like a flowlet it flow. Based on the data analysis, it was found that dancing as the symbols of freedom has been expressed into many interpretation, consisting of dancing expressing her freedom of being life, of taking back her rights, of avoiding Western aesthetic principles, of being peaceful state of mind, of finding her desire, of gaining a deep hypnotic trance, of gaining humanity instead of being prejudice of her nationality, and of avoiding Western civilization.

Prior to discussing the aforementioned findings, the researcher is curious to know what makes the 'dancing' has many symbols of freedom. This was evidenced that the novel of Namaku Mata Hari tells about a woman named Margaretha Geertruida who later changed her name to Mata Hari. She is a beautiful and clever girl who is very honest about her feelings especially her feelings regarding sex. She married a man who is double her age. She was hoping a happy family at the beginning but unfortunately her husband, John Rudolph Macleod, was not as good as she expected. 


\section{Interpreting Dancing as Symbols of Freedom in Remy Sylado's Namaku Mata Hari}

from Its Protagonist Personality

He treats her in a very bad way possible for a wife throughout their marriage that makes her want to take a revenge on him. He is like a cage for her so she wants to be freed from him. She finds pleasure through dancing and also having sex. She likes to be in Borobudur, a place where she can get the freedom that she needs. Throughout the novel, Mata Hari often emphasizes that she is the happiest and freest when she is dancing-naked. Her career as an erotic dancer and as a doubleagent for France and Germany in the World War I that begins from her revenge to her husband are the main issues in this novel.

The symbol in this novel is in the form of the total action, which is dancing. Mata Hari loves to dance since she was a child as shown in this quotation:

"Sejak kecil aku suka menari." Mata Hari (Sylado, 2011: 38)

The statement above states that dancing is her life. She enjoys dancing as well as watching people dance. She finds happiness and relaxation through the movement of the dance. She has always dreamed of being a dancer when she was a teenager. Her id desperately wants to dance. However, her dreams and happy life then change into a disaster after she married to Ruud, as she called him. Ruud later prohibits her to dance.
Dalam keadaan begini Ruud muncul.

Dia tidak memuji aku.

Dia menghina aku.

“Wat 'n schandaal," katanya sembari menyeret aku dari arena langsung ke bawah. (Sylado, 2011: 50)

He insults her of doing so in public area. He treats her in a mean way and he even takes her rights of doing what she wants, or in the broader sense, he limits her freedom. On the view of freedom, Hayek (1960: 12) writes that,

"The original meaning of the word 'freedom' meant always the possibility of a person's acting according to his own decisions and plans, in contrast to the position of one who was irrevocably subject to the will of another, who by arbitrary decision could coerce him to act or not to act in specific ways. The timehonored phrase by which this freedom has often been described is therefore independence of the arbitrary will of another. In this sense 'freedom' refers solely to a relation of human beings to other human beings, and the only infringement on it is by coercion by 
other human beings.” (Hayek, 1960:

Hayek explains that freedom means the rights of a person to do what he wanted according to his own decisions and plans ${ }^{7}$. Ruud who coerces Mata Hari from following her own will has taken her freedom. However, despite the prohibition of her husband she still thinks that dancing is her life. She wants to get her freedom back. It can be seen on her thought about how her life will be in Indonesia, one thing that comes to her mind is dancing.

Deep inside, her id still controls her ego. This coincides with the concept of Id proposed by Freud (1940) stating that Id exist in the human unconscious and does not have any direct context to the external world. Due to this fact, id is considered to be irrational. Id only knows how to fulfil its wishes without having any knowledge of social norms. It cannot differentiate goods or bads, rights or wrongs. In other words, id does not have morality. Controlling her ego means that she never lets the thought of getting pleasure from dancing out of her mind.

Ketika aku mengangan-angankan ini, yang melintas dalam pikiranku adalah menari, bagaimana aku merdeka dari kaidah estetika Barat yang terlalu teknis dalam tarian-

\footnotetext{
${ }^{7}$ Friedrich A. Hayek, The Constitution of Liberty (Chicago: Chicago University Press)
}

tariannya, lalu membiarkan tubuhku bergerak leluasa di bawah nadanada gending yang secara alami menyugesti bahasa tubuhku dalam suatu kaidah estetika yang murni, lugu, liar, dan baru. Sampai sejauh ini, bahkan setelah aku nikah dan tinggal di Indonesia.... aku belum berpikir bahwa dengan bisa menari membebaskan tubuhku dari kaidahkaidah gerak estetika Barat (Sylado, 2011: 17).

It is obvious now that the ego plays the role "as an intermediary between the id and the external world (Freud, 1940)." Unlike the id, the ego is rational and works depending to the reality principle. For this reason, the ego will not sastisfy the demands of id immediately. Hence, it is believed that in doing action the ego have gone through a complicated process both in human's conscious and unconsciousness. It is the actor of human's personality system which has two main functions. First, it should choose which instinct to satisfy according to the needs priority. Second, it must decide the right time and the right way to sastisfy the needs without crashing with the reality principle. Thus, every action by the ego will try to satisfy the demands of id while in the meantime it should also consider the norms of super ego (Freud, 1940). 


\section{Interpreting Dancing as Symbols of Freedom in Remy Sylado's Namaku Mata Hari from Its Protagonist Personality}

Western aesthetic principles play the role as super-ego for Mata Hari's personality structures. In relation to this issue, super ego functions as the rules, norms, traditions, or anything which is socially correct that people got as they are growing up (Freud, 1940). People usually got this system from their parents when they were a child. Parents taught their children about what is being socially appropriate or inappropriate. They told these rules in the form of commands and prohibitions. Then, the children will have the knowledge of what is right or wrong. Their view of what is right is known as the ego ideal, and their view of what is considered to be wrong is called conscience.

Referring to the Western aesthetic principles, the principles view a girl dancing in public as socially is inappropriate. However, she believes that dancing will make her free from the Western aesthetic principles which are too formal and static. For this reason, the writer believes that dancing signifies freedom for Mata Hari rather than as just a movement of her body back and forth for the purpose of nothing. As Augustine explain that people should not regard something for what they are in the literal context "but rather for their value of as signs which signifies something else." Moreover, she is not an ordinary dancer, for she is an erotic one. The pressure and pain that Ruud gives to her encourages her of being so. In this matter, he leads her to do many socially inappropriate things for the purpose of paying back what he has done to her.

Aku menjadi begini karena suamiku MacLeod yang aku panggil Ruud. (Sylado, 2011: 10)

Sekali lagi dia sudah melukai perasaanku, dia menggiring aku untuk berpikir balas dendam... (Sylado, 2011: 80)

"Macleod's bad temper worsened and he was mean to servants as well as his wife. He openly took a native woman, a babu, my babu, as a concubine, and informed that such practice was customary in this neck of woods, so I would just have to adjust to it. he was often drunk and enjoyed marital rapes." -Mata Hari (Sylado, 2011:472)

Mereka tetap tidak bertanya. Rupanya mereka menyerap betul masalahku. Mungkin mereka mengerti mengapa aku sekarang menjadi Mata Hari yang begini seronok. (Sylado, 2011: 472)

She wants to dance in order to be in a peaceful state of mind and at the same time to take revenge on Ruud. By doing that 


\section{Jurnal al-Tsaqafa Volume 15, No. 01, Juli 2018}

kind of dance, she has fulfilled her quench of happiness and freedom and at the same time satisfied the demands of her id. His rude and cruel behavior towards her in their marriage specifically his hunger on sex and women has torn her apart. She did not get the happy family that she wanted so the id views this as a pain. Hence it tries to get as many pleasures as it can for the purpose of reducing the pain. It can be seen from her statement after having a fierce fight about she letting the maid go. She feels terrible inside, even so, in this situation she says something about dancing.

"Saya cemburu melihat burungburung perenjak berkicau di ranting-ranting kembangsepatu, seolah-olah girang menyanyi dan menari di situ." (Sylado, 2011: 85)

She says explicitly in this quotation that she wants to be like the birds who can sing and dance happily. The id views dancing as its ultimate source of pleasure and freedom, and the ego wants to satisfy this demand. Her statement afterwards proves that dancing does mean freedom for her.

Manalah mungkin orang menyanyi dan menari ketika orang itu tidak menemukan jalan menuju pembebasan terhadap rasa benci?" (Sylado, 2011: 85)

The freedom that she talks about is not only concerns of coercion from other people towards herself but also the freedom from her own feelings. Hospers (1984) argued that "though freedom from the arbitrary will of other persons is the principal way one can have freedom-from, there are other things one can be free-from besides the will of other human beings. ${ }^{8}$ " This statement is in line with what happens to Mata Hari as she freed herself from her own hatred over her husband.

Her interest in erotic dance first aroused when she was visiting Mbah Kung's art studio on the banks of Kali Elo. She watched a girl was dancing while taking her clothes off. Watching this performance, she believes that this exemplifies freedom and liberty.

Dia turun dari tandu, kemudian menari di tengah lelaki-lelaki, melepaskan baju yang menutup dada, sehingga payudaranya yang tidak terlalu besar, kira-kira sama idealnya dengan ukuran payudaraku, bebas merdeka diterpa sepoi angin malam." (Sylado, 2011: 88)

It is clear from this quotation that she thinks of dancing "beyond the impression the dancing itself makes upon the senses" as Augustine would say. She has found her desire and without thinking much, she insisted on doing the same as the girl from

\footnotetext{
${ }^{8}$ John Hospers, The Meanings of Freedom (1984)
} 


\section{Interpreting Dancing as Symbols of Freedom in Remy Sylado's Namaku Mata Hari}

from Its Protagonist Personality

earlier has done. In this moment, the id finally met its demand on pleasure.

Tanpa sungkan aku meminta kepada pemimpin sanggar untuk ikut menari.

Dalam beberapa putaran - aku tak ingat sebab benar-benar menikmati - serasa tubuhku melayang dalam ekstase. Aku merasa tubuhku telah menjadi medium roh Siwa sang raja penari. (Sylado, 2011: 89)

The symbol in this quotation is shown by Mata Hari's description of the feelings she got while she is dancing. A symbol is "a word or phrase that signifies an object or event which in its turn signifies something, or has a range of reference, beyond itself" (Abrams, 1999: 311). A symbols is used to symbolize something which is usually greater than the symbol itself. Symbols are frequently used in literary works. The author often uses symbol for various reasons, for instance in addressing a sensitive issue or to criticize a particular community. In these contexts, the author explains a complicated matter in a simple way. The readers will interpret these symbols differently according to their own views. Some factors such as educational level and cultural traditions will also affect the reader in interpreting a symbol.
Through her words, she explained that she went into a deep hypnotic trance. It shows how much she enjoyed the movement. However, those "words are shown to the eyes, not in themselves but through certain signs which stand for them" (Augustine in Nurrachman, 2017: 95). Dancing has given her peace of mind as shown in the quotation below.

Ah, aku mau menari lagi. Senyampang di tempat di mana aku merasa damai begini. Aku akan menari sampai badanku letih lalu tidur nyenyak. (Sylado, 2011: 90)

Through dancing, she gets very much pleasure in the form of a deep hypnotic trance and a peaceful state of mind. She forgets the pain she got from Ruud for a brief moment. She can release her stress and every pressure from her marriage life in this situation.

Mata Hari is a Dutch woman of Indonesian descent. Consequently, she can speak Dutch and Indonesian, which includes fluent Javanese and basic Sundanese. In fact, she says that she speaks seven languages fluently. However, she does not like to be distinguished by her nationality. She prefers the terms humanity instead. 
Di sini aku merasa benar-benar menjadi manusia, bukan bangsa. (Sylado, 2011: 94)

Mata Hari's super ego does not very much affect her action. She does not take into account most of Western aesthetic principles which logically should act as her super ego.

During her stay in Mbah Kung's place, she feels that she becomes a truly human, not a part of a nation. This indicates that she is free from every prejudice possible regarding her nationality. What she feels when she is dancing is the same as her ideology which prefers the term 'humanity' to 'nationality'. She considers that nationality is a complicated matter particularly for the people of mixed race. Thus, she sees herself not as a part of a certain nationality but only as a human instead, a common human among other humans.

Aku sengaja diam di sanggar seni di pinggir Kali Elo ini, menikmati hidup bebas di tanah nan gemah ripah loh jinawi (Sylado, 2011: 105).

Once again in the quotation above she tells that being there makes her feel her freedom, the feelings that she never gets during her marriage life with Ruud. Therefore, when Didik asked her if she did not have any intention on coming back to Borobudur again to dance with the people there, she said there is no way she did not want to.

"Rasanya jiwa saya ada di sana," Mata Hari (Sylado, 2011: 116)

"Bagian dinding candi yang melukiskan dua penari itu serasa menjadi bagian dari tubuh saya. "Mata Hari (Sylado, 2011: 116)

"The temple is Borobudur. But my temple is here in my heart. The temple which I dance can be vague of faithfully reproduced, as here today. For I am the temple. All true temple dances are religious in nature, and all explain, in gestures and poses, the rules of the sacred texts.”-Mata Hari (Sylado, 2011: 473)

Her soul and body have united with the relief that shows two dancers and with the Borobudur temple itself. It is the highest feelings that one can get once he/she is free from anything that prevents he/she from feeling so.

Dalamnya tak sadar aku telah berpikir tentang suatu kemauan rohani untuk melepaskan diri dari ikatan-ikatan jasmani yang mungkin menghambat kemauan lain di baliknya. (Sylado, 2011: 117)

She is willing to set herself free from all the bonds of material and physical possession. She believes that once she frees herself from those things, she can do 


\section{Interpreting Dancing as Symbols of Freedom in Remy Sylado's Namaku Mata Hari}

from Its Protagonist Personality

whatever she wants by following her inner desire-the id. The bonds of material aspect in this quotation signifies her marriage life with Ruud. Thus, her inner desire of freedom is signified through dancing for she feels the most peaceful inside and outside when she is dancing.

Rasanya tidak ada kembaran rasa indah yang lain, selain yang diberi oleh udara sekitar Borobudur. Di sini aku merasa damai: damai di bumi, damai di hati. (Sylado, 2011: 147)

Her love for dancing is proven clearly when she said that she does not want to die as a part of a nation, but as a naked dancer instead.

Suatu waktu nanti, kalau aku sudah tidak ada, sebab kematian adalah suatu kepastian dalam kehidupan, maka aku ingin mati sebagai manusia biasa, bukan bangsa tertentu dengan bahasa kebangsaannya, tapi tetap sebagai sosok penari telanjang. (Sylado, 2011: 13)

This quotation signifies that being a naked dancer is her passion and also her happiest time, extremely happy that she is willing to be remembered as a dancer even after her death.
"Saya tidak mau mata ditutup dengan kain hitam apapun. Saya malah ingin mencopot semua kain yang menjadi pakaian saya, supaya tubuh saya bisa bebas dari segala beban peradaban Barat yang seluruhnya palsu." -Mata Hari (Sylado, 2011: 558)

Western civilization is the thing that prevents her from getting her freedom. It includes the rules in marriage life, the rules for dressing, what women should and should not do, and mostly other feminist issues. She regards this principles that Western people obey as fake and crooked. Later, she found her freedom by dancing, taking off her clothes, and having sex with her affairs.

"My dance is a sacred poem in which movement is a word, and whose every word is underlined by music, the gending." -Mata Hari (Sylado, 2011: 473)

This final quotation of this essay proves that dancing is a symbol that symbolize something bigger than what it really is as said by Mata Hari herself. It then lies in the process of interpretation of the reader. However, the writer believes that it symbolizes freedom concerning Hospers' (1984) and Hayek's (1960) theories of freedom as well as Mata Hari's statements 


\section{Jurnal al-Tsaqafa Volume 15, No. 01, Juli 2018}

and feelings towards dancing. Western civilization and Ruud coerce her from getting her freedom, but she can get it through dancing.

The relation of a symbol and what it symbolize is arbitrary (Saussure in Nurrachman, 2018: 16). The dove, for example, is a symbol of peace. Logically there is no direct relation between this particular bird with peace as there is no exact relation of the colour pink and love. However, many people take these symbols for granted without questioning about them anymore. Besides many symbols which are already known to the society, readers can interpret a new symbol for various things as long as the have logic arguments to prove their arguments:

The first theory of symbol -or sign- is due to St. Augustine (AD 354-430) in his book On Christian Doctrine. He examines symbols which exist in the Bible as something that human should not take literally. Many things stated in the Bible signify something bigger than they really are. They usually have a broader meaning in which a concrete object often signifies an abstract thing.

Augustine (in Nurrachman, 2017: 86) defines signs as "things used signify something" in the process of signification. After a few centuries, Saussure, a linguist, proposed a more detailed explanation for this matter. Saussure (in Nurrachman, 2018: 15) argued that linguistic sign is not the combination of a thing and a name, but rather of a concept and a sound-image. Saussure prefer to replace the former as the signified and the latter as the signifier respectively.

The most common form of a sign is a word "for no one uses words except for the purpose of signifying something" (Augustine in Nurrachman, 2017: 88). Whereas other objects can also be used to signify something, a word is the most frequently used among them. Furthermore, Augustine explained that there are two kinds of sign, natural and conventional. Natural sign is the sign that simply found in nature and does not have any figurative meaning. This kind of symbol is basically the way it is. It does not represent anything beyond itself. Meanwhile, conventional sign is different from the former because it is made by humans. Symbols are one of the examples of conventional sign.

Nair (2010) argued that "most commonly, a symbol will present itself in the form of: 1) a word, 2) a figure of speech, 3) an event, 4) the total action, or 5) a character." From this definition, it can be concluded that everything can play the role as a symbol for another thing. A symbol may appear in a literary fiction in a number of different ways to symbolize a number of different things (Nair, 2010). It can suggest friendship, love, peace, death, freedom and so on. 


\section{Interpreting Dancing as Symbols of Freedom in Remy Sylado's Namaku Mata Hari}

from Its Protagonist Personality

\section{B. CONCLUSION}

Mata Hari's id wants to obtain as much as pleasure as possible. She believes that one of the ways to get this pleasure is by acquiring her freedom. According to the theories of freedom from Hayek (1960) and Hospers (1984), the term freedom can be defined as a state in which one is free to do everything according to his/her will and plans without any coercion from others. The coercion here is not only from others' arbitrary will but also from one's own feelings and thoughts. This kind of freedom is often called as personal or individual freedom. Thus, 'freedom' can be defined as only the relation among human beings with its only infringement is the coercion by other human beings (Hayek, 1960). Hayek focused on the coercion that according to him take away people's right in order to get their freedom.

In addition to the previous definition of freedom, Hospers (1984) in his article The Meanings of Freedom described the term freedom in a more detailed way from that of Hayek's. He broadened the sense of freedoms-from and freedoms-to as not only to be free from the will of other human beings but there are other things one can be free-from. Many things according to him prevent people in the way of getting their happiness. These things can be a disease, a traumatic experience, an old-fashioned mindset, or one's own feeling and thought towards something.

In many occasions, Mata Hari often hinted that she is the freest and the happiest when she is dancing. However, this action of her is completely opposed by the Western aesthetic principles which in this case play the role as her super ego. Even though, her ego prefers to cooperate with the id and many times ignore the beliefs of the super ego.

Throughout the novel, it can be concluded that from dancing she succeeds to express her freedom of being life, to get her rights back, to avoid Western aesthetic principles, to have peaceful state of mind, to find her desire, to gain a deep hypnotic trance, to gain humanity instead of being prejudice of her nationality, and to avoid Western civilization.

\section{REFERENCES}

Abrams, M. H. A Glossary of Literary Terms. Boston: Earl McPeek, 1999.

Cresswell, J. Educational Research: Planning, Conducting, and Evaluating Quantitative and Qualitative Research. Boston: Pearson, 2012.

Djajasudarma, T. Fatimah. Dasar-Dasar Linguistik Umum. Jakarta: FSUI, 2010 . 
Freud, Sigmund. "An Outline of PsychoAnalysis." International Journal of Psycho-Analysis (1940): 27-84.

Hayek, Friedrich A. The Constitution of Liberty. Chicago: Chicago University Press, 1960.

Hospers, John. "The Meanings of Freedom." (1984).

Kolb, Alexandra. Mata Hari's Dance in the Context of Femininity and Exoticism. Mandrágora, 2009.

Nair, T. Symbolism in Literature. 2010. $<$ http://www.buzzle.com/articles/sy mbolism-in-literature.html> .

Nurrachman, Dian. Introduction to Criticism: Critical Theory from Ancient Greece to Victorian England. Bandung: Pustaka Aura Semesta, 2017.

Puspitaningrum, Yohana Dwi. An Analysis of Protagonist's Self Predicament in Remy Sylado's Namaku Mata Hari: A Psychoanalysis Perspective. Unpublished Paper, 2013.

Sabariah, Dita. Mata Hari Sebagai Perempuan Intelijen Dalam Novel Namaku Mata Hari Karya Remy Sylado: Sebuah Analisis Berperspektif Gender. Unpublished Paper, 2011.

Seidman, I. Interviewing as Qualitative Research. New York: Teachers College Press, 2006.
Sudaryanto. Metode dan Teknik Analisis Bahasa. Yogyakarta: Wacana University Press, 1993.

Sylado, Remy. Namaku Mata Hari. Jakarta: Gramedia Pustaka Utama, 2011.

Todorov, Tzvetan. Tata Sastra. Diterjemahkan ke dalam bahasa Indonesia oleh Okke K.S. Zaimar, dkk. Jakarta: Djambatan, 1985.

Wellek, Rene \& Austin Warren. Teori Kesusastraan (diterjemahkan oleh Melani Budianta). Jakarta: Gramedia, 1990.

Zhang, Q. "Fuzziness, Vagueness, Generality, Ambiguity." Journal of Pragmatics. 29(1) (1998): 13-31. 